Phar macoet hni ci ty of docet axel - i nduced severe neut ropeni a: i nt egr at ed anal ysi s of publ i shed phase II and III trial S

\begin{tabular}{|l|l|}
\hline 著者 & $\begin{array}{l}\text { YANO Ryoi chi, KONNO Aya, WATANABE Kyohei, } \\
\text { TSUKAMOTO H t oshi, KAYANO Yui chi ro, OHNAKA } \\
\text { H r oaki, GOTO Nobuyuki, NAKAMURA Toshi aki , } \\
\text { MASADA M ki o }\end{array}$ \\
\hline $\begin{array}{l}\text { j our nal or } \\
\text { publ i cat i on ti tl e }\end{array}$ & I nt er nat i onal Jour nal of Cl i ni cal Oncol ogy \\
\hline vol une & 16 \\
\hline number & 6 \\
\hline year & $2011-11$ \\
\hline URL & ht t p: //hdl . handl e. net $/ 10098 / 4847$ \\
\hline
\end{tabular}




\title{
Pharmacoethnicity of docetaxel-induced severe neutropenia: integrated analysis of published phase II and III trials
}

\author{
Ryoichi Yano • Aya Konno $\cdot$ Kyohei Watanabe $\cdot$ \\ Hitoshi Tsukamoto - Yuichiro Kayano - Hiroaki Ohnaka • \\ Nobuyuki Goto $\cdot$ Toshiaki Nakamura $\cdot$ Mikio Masada
}

Received: 3 April 2011/Accepted: 31 October 2011

(C) Japan Society of Clinical Oncology 2011

\begin{abstract}
Background Ethnic differences in drug susceptibility and toxicity are a major concern, not only in drug development but also in the clinical setting. We review the toxicity profiles of docetaxel according to dose and ethnicity.

Methods We analyzed phase II and III clinical trials that included a once-every-3-weeks single-agent docetaxel arm. Logistic regression analysis was applied to identify the significant variables affecting the reported incidence of docetaxel-induced severe neutropenia.

Results Multivariate logistic regression analysis identified studies conducted in Asia [odds ratio (OR) 19.0; 95\% confidence interval $(95 \% \mathrm{CI}) 3.64-99.0]$ and docetaxel dose (OR 1.08; 95\% CI 1.03-1.13) as independent variables for the incidence of grade 3/4 neutropenia.

Conclusions There is a significant difference in the incidence of docetaxel-induced severe neutropenia between Asian and non-Asian clinical studies. Physicians and pharmacists should consider ethnic diversity in docetaxel toxicity when interpreting the results of clinical trials.
\end{abstract}

Keywords Ethnic differences $\cdot$ Docetaxel $\cdot$ Logistic regression $\cdot$ Neutropenia

R. Yano $(\bowtie) \cdot$ A. Konno $\cdot$ K. Watanabe $\cdot$ H. Tsukamoto

Y. Kayano · H. Ohnaka $\cdot$ T. Nakamura · M. Masada

Department of Pharmacy, University of Fukui Hospital,

23-3 Matsuokashimoaizuki, Eiheiji-cho,

Yoshida-gun, Fukui 910-1193, Japan

e-mail: yanor@u-fukui.ac.jp

\section{N. Goto}

Department of Drug Informatics, Faculty of Pharmaceutical

Sciences, Meijo University, 150 Yagoto-yama,

Tempaku-ku, Nagoya 468-8503, Japan

\section{Introduction}

One of the major concerns in the international harmonization of drug development is the issue of pharmacoethnicity. Pharmacoethnicity can be described as ethnic diversity in drug response or toxicity, which includes a large number of factors including genetic and environmental components and social divergence $[1,2]$.

In the area of oncology, some reports have discussed ethnic differences in treatment effects and toxicity. For example, gefitinib, an epidermal growth factor receptor (EGFR) tyrosine kinase inhibitor that has been used for the treatment of EGFR-positive non-small-cell lung cancer, was reported to have a minimal effect on survival in a large multi-regional placebo-controlled phase III trial, despite a significant increase in survival in patients of Asian origin [3]. This diversity might be explained, in part, by differences in the frequency of EGFR mutations, a major predictive factor of gefitinib efficacy [4]. Other studies examined the combination of irinotecan and cisplatin for the treatment of advanced small cell lung cancer. The use of irinotecan plus cisplatin for the treatment of extensivestage small cell lung cancer was first reported by Japanese researchers (JCOG 9511), and it was shown to have a superior survival effect over the conventional standard regimen of etoposide plus cisplatin [5]. However, trials in North America failed to confirm the survival benefit of irinotecan-containing regimens $[6,7]$. One of these studies, the SWOG S0124 trial, included pharmacogenomic investigations. The authors stated the potential importance of pharmacogenomics in interpreting the results of clinical trials in cancer therapy [6].

In 2008 , the combination of $75 \mathrm{mg} / \mathrm{m}^{2}$ docetaxel with prednisolone was approved in Japan for the treatment of hormone-refractory prostate cancer on the basis of results 
from a Japanese phase II trial [8] and a Western phase III trial (TAX327) [9]. In these two clinical studies, several differences were found, including the doses of docetaxel and their outcomes and safety profiles. In the Japanese phase II trial, $70 \mathrm{mg} / \mathrm{m}^{2}$ docetaxel was used, whereas the TAX327 trial used $75 \mathrm{mg} / \mathrm{m}^{2}$ docetaxel. Grade $3 / 4$ neutropenia and febrile neutropenia occurred in 93.0 and $16.3 \%$ of patients in the Japanese study compared to 32 and $3 \%$ of patients in the TAX327 trial, respectively. These results suggested that docetaxel was more toxic to Japanese patients, despite the use of a lower dose. In Japan, docetaxel has been approved at doses of $60-70 \mathrm{mg} / \mathrm{m}^{2}$ for the treatment of gastric cancer, non-small-cell lung cancer, esophageal cancer, ovarian cancer, and uterine corpus cancer. These approved doses of docetaxel in Japan are much lower than those in Western countries.

According to these observations, we analyzed the differences in the incidence of docetaxel-induced severe neutropenia between clinical trials conducted in Asian and non-Asian countries using published data as a model to study ethnic diversity in drug susceptibility.

\section{Materials and methods}

\section{Search strategy}

Phase II and III clinical trials that included a treatment arm of docetaxel monotherapy administered at 3-week intervals were considered in this review. Meeting abstracts were excluded. Studies that used glucocorticoids with docetaxel were also included. Only reports written in English or Japanese were included in the analysis.

An electronic database search was performed using PubMed, the Cochrane Controlled Trials Register by Ovid (EBM reviews, 4th quarter, 2009), and Ichushi-Web (a domestic medical literature database service provided by the NPO Japan Medical Abstracts Society) on November 30, 2009. The keyword used for the electronic database search of PubMed was "docetaxel" with limitations by the type of articles of "clinical trials, phase II", or "clinical trials, phase III". For the other databases, we used "docetaxel" as a keyword.

\section{Selection criteria}

Surveys and retrospective studies were not included in the analysis. Reports of interim analysis were also excluded. In addition, reports that contained the incidence of grade $3 / 4$ neutropenia only as a percentage of treatment courses were excluded. Finally, studies adopting primary prevention with granulocyte-colony stimulating factor were also excluded.
Study selection

Two authors independently assessed the titles and abstracts of all identified articles. Disagreements between the reviewers were resolved by consensus. Two authors evaluated the full text of the selected papers and determined their inclusion or exclusion in the analysis according to the eligibility criteria.

\section{Data extraction}

Two authors extracted data for trial phase, treatment line, types of malignancy, number of patients treated with docetaxel, dose of docetaxel, median age, percentage of females, percentage of patients whose performance status (defined by the World Health Organization/Eastern Cooperative Oncology Group) was $>1$, the region where the study was conducted, and the incidence of grade $3 / 4$ neutropenia as a percentage of patients.

\section{Statistical analysis}

Univariate and multivariate analyses were conducted to identify the factors influencing the higher incidence of grade $3 / 4$ neutropenia in the docetaxel monotherapy arm in each report. A $>70 \%$ incidence of grade 3/4 neutropenia was defined as a higher incidence. The dose of docetaxel, percentage of females, median age of participants, percentage of patients whose performance status was $>1$, treatment line, trial phase, and the region where the study was mainly conducted were considered as candidate variants. The treatment line was classified into 2 groups: the adjuvant, neoadjuvant, and first line were encoded as 0 , while the second line or subsequent lines were encoded as 1 . The region where the study was mainly conducted was grouped as Asia or non-Asia. The dose of docetaxel, median age of participants, and percentage of patients whose performance status was $>1$ were forcibly included into the multivariate analysis because they are known risk factors for the incidence of neutropenia with docetaxel. The variables that showed a moderate relationship $(p<0.2)$ with a higher incidence of grade $3 / 4$ neutropenia in the univariate analysis were included in the multivariate analysis. The final model was built by stepwise logistic regression. The variables were selected using Wald's likelihood ratio, with $p$ values of $<0.1$ for exclusion and $<0.05$ for inclusion. A HosmerLemeshow goodness-of-fit test was performed to examine the calibration of the model. All statistical analyses were performed using SPSS statistics version 17.0 (SPSS Japan Inc., Tokyo, Japan). 


\section{Results}

Literature search

We identified 1010 citations by database search, of which 153 articles were retrieved and reviewed. We excluded papers that did not contain adequate patient demographics or outcomes $(n=21)$, studies with a dosage regimen that did not meet our criteria $(n=8)$, and review papers or papers containing combined analyses $(n=4$; Fig. 1$)$. Ultimately, 128 arms from 120 studies were used for further analysis [8-127].

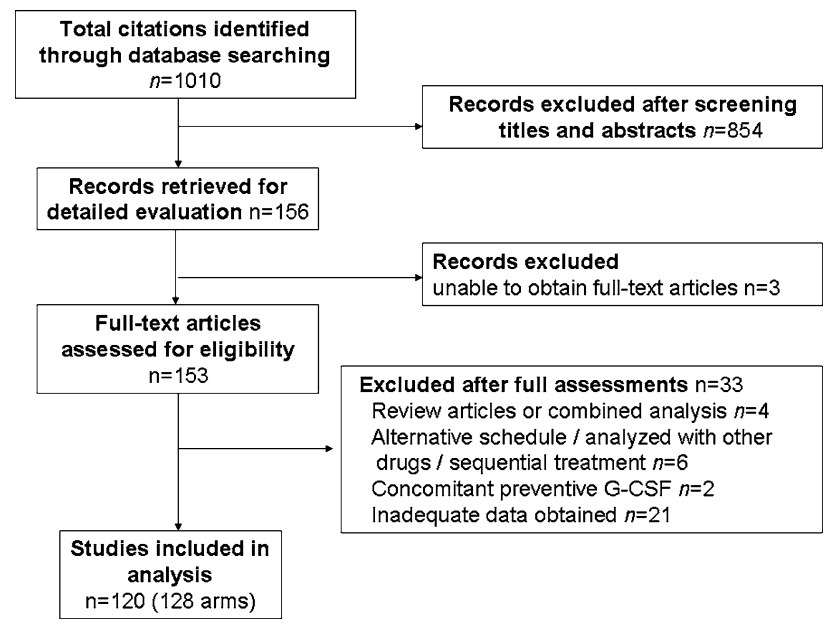

Fig. 1 Study selection
Characteristics of the reports

The characteristics of the reports reviewed are presented in Table 1 . The size and number of the study arms classified by docetaxel dose were 1535 patients in 24 arms, 25 patients in $1 \mathrm{arm}, 274$ patients in 6 arms, 4034 patients in $30 \mathrm{arms}$, and 3880 patients in 67 arms for $60,66,70,75$, and $100 \mathrm{mg} / \mathrm{m}^{2}$ docetaxel, respectively. Of these arms, the numbers of studies conducted in Asia and their participants were 1384 patients in 23 arms, 25 patients in $1 \mathrm{arm}, 225$ patients in 5 arms, 141 patients in 3 arms, and 35 patients in 1 arm for $60,66,70,75$, and $100 \mathrm{mg} / \mathrm{m}^{2}$ docetaxel, respectively. The minimum number of participants in an arm was 12 . The majority of the participants were nonsmall-cell lung cancer and breast cancer patients. The majority of studies conducted in Asia were Japanese studies (1609 Japanese participants in 28 arms out of 1810 Asian participants in $33 \mathrm{arms})$. The others Asian studies were conducted in South Korea, Taiwan, and Singapore. All of the studies conducted in Japan used docetaxel at doses of $70 \mathrm{mg} / \mathrm{m}^{2}$ or lower. In particular, phase III trials conducted in Asia were performed using $60 \mathrm{mg} / \mathrm{m}^{2}$ docetaxel. There were 10 reports written in Japanese that contained 745 Japanese participants.

Distribution of the reported incidence of grade $3 / 4$ neutropenia

The relationship between the dose of docetaxel and the incidence of grade 3/4 neutropenia is presented in Fig. 2. The weighted means of the reported incidence of grade $3 / 4$ neutropenia, which were calculated by dividing the total number of participants who experienced grade 3/4

Table 1 Characteristics of the study arms

\begin{tabular}{|c|c|c|c|c|c|c|c|c|c|c|}
\hline \multirow{2}{*}{$\begin{array}{l}\text { Docetaxel dose }\left(\mathrm{mg} / \mathrm{m}^{2}\right) \\
\text { Trial phase }\end{array}$} & \multicolumn{2}{|l|}{60} & \multicolumn{2}{|l|}{66} & \multicolumn{2}{|l|}{70} & \multicolumn{2}{|l|}{75} & \multicolumn{2}{|l|}{100} \\
\hline & II & III & II & III & II & III & II & III & II & III \\
\hline Number of study arms (Asia) & 19 (19) & $5(4)$ & $1(1)$ & $0(0)$ & $6(5)$ & $0(0)$ & $18(3)$ & $12(0)$ & $53(1)$ & $12(0)$ \\
\hline \multicolumn{11}{|l|}{ Sample size (by arm) } \\
\hline $12-50$ & 10 & 0 & 1 & 0 & 5 & 0 & 12 & 0 & 46 & 2 \\
\hline $51-100$ & 9 & 2 & 0 & 0 & 1 & 0 & 6 & 2 & 8 & 2 \\
\hline $101-200$ & 0 & 2 & 0 & 0 & 0 & 0 & 0 & 4 & 1 & 6 \\
\hline$\geq 201$ & 0 & 1 & 0 & 0 & 0 & 0 & 0 & 6 & 0 & 2 \\
\hline $\begin{array}{l}\text { Total number of participants } \\
\text { (in Asian studies) }\end{array}$ & 839 (839) & $696(545)$ & $25(25)$ & $0(0)$ & $274(225)$ & $0(0)$ & $824(141)$ & $3210(0)$ & $2290(35)$ & $1590(0)$ \\
\hline \multicolumn{11}{|l|}{ Types of tumor } \\
\hline Non-small-cell lung & 5 & 3 & 1 & 0 & 1 & 0 & 11 & 8 & 8 & 5 \\
\hline Breast & 4 & 2 & 0 & 0 & 0 & 0 & 1 & 3 & 14 & 7 \\
\hline Others & 10 & 0 & 0 & 0 & 5 & 0 & 6 & 1 & 33 & 0 \\
\hline
\end{tabular}


neutropenia by the total number of participants for each docetaxel dose, were $70.1,68.9,50.0$, and $75.3 \%$ for 60 , 70,75 , and $100 \mathrm{mg} / \mathrm{m}^{2}$, respectively.

\section{Logistic regression}

The results from the univariate and multivariate logistic regression analyses are shown in Table 2 . From the univariate analysis, studies conducted in Asia $(p=0.073)$, treatment line $(p=0.057)$, and the percentage of females ( $p=0.082)$ were included in the subsequent multivariate analysis. The dose of docetaxel $(p=0.266)$, the median age of participants $(p=0.300)$, and the percentage of patients whose performance status was $>1(p=0.287)$ did not meet

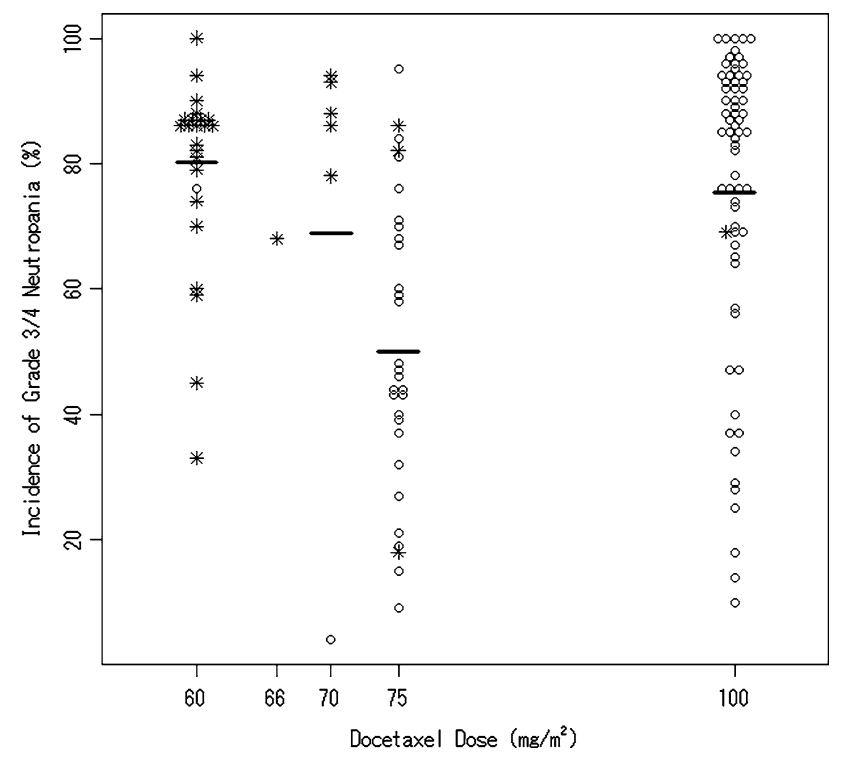

Fig. 2 Incidence of severe neutropenia. The incidence of grade 3/4 neutropenia reported in each paper was plotted. Each symbol represents a treatment arm that included a single-agent docetaxel arm. The open circles represent studies conducted in non-Asian countries. The asterisks represent studies conducted in Asian countries. The horizontal bars represent the weighted means of the reported incidence of grade 3/4 neutropenia for each docetaxel dose, for which sample size was used as a weight the criteria, but were forcibly included in the subsequent multivariate analysis. Trial phase ( $p=0.276)$ was excluded. Multivariate analysis identified studies conducted in Asia [odds ratio (OR) 19.0; 95\% confidence interval $(95 \% \mathrm{CI}$ ) 3.64-99.0; $p<0.001$ ] and the dose of docetaxel (OR 1.08; 95\% CI 1.03-1.13; $p=0.001)$ as independent variables for the incidence of grade 3/4 neutropenia. The percentage of patients whose performance status was $>1$ (OR 0.99; 95\% CI $0.96-1.02 ; p=0.444)$ and the median age of participants (OR 1.02; 95\% CI 0.94-1.10; $p=0.598$ ) were not identified as significant variables. The percentage of females and treatment line were not included in the final model. The Hosmer-Lemeshow goodness-of-fit test suggested a good calibration $(p=0.492)$. The predictive accuracy of this model was $76.6 \%$.

\section{Discussion}

We confirmed that docetaxel had a higher toxicity in Asian studies than in non-Asian studies. The studies performed in Asia showed an almost 19 times higher risk for severe neutropenia compared with the non-Asian studies.

Docetaxel has been one of the most important cytotoxic drugs in the treatment of major tumors such as breast cancer, non-small-cell lung cancer, and prostate cancer. This indicates that docetaxel will be used as a reference regimen in future clinical trials. However, the heterogeneity of docetaxel-induced toxicity profiles between Asian and non-Asian countries is a major problem due to the resulting variations in the recommended dose of docetaxel. This also represents a serious concern in the clinical setting. Physicians and pharmacists should consider ethnic diversity in docetaxel toxicity when interpreting the results of clinical trials.

One of the possible mechanisms that influence the ethnic diversity in docetaxel toxicity is pharmacogenomic differences in drug-metabolizing enzymes and/or drug transporters. Recently, a US-Japan common-arm trial reported diversity in the clinical outcomes, including survival and neutropenia, between US and Japanese non-small-cell

Table 2 Logistic regression analysis

\begin{tabular}{|c|c|c|c|c|c|c|}
\hline & \multicolumn{3}{|c|}{ Univariate analysis } & \multicolumn{3}{|c|}{ Multivariate analysis } \\
\hline & OR & $95 \% \mathrm{CI}$ & $p$ & OR & $95 \% \mathrm{CI}$ & $p$ \\
\hline Studies conducted in Asia & 2.20 & $0.93-5.22$ & 0.073 & 19.0 & $3.64-99.0$ & $<0.001$ \\
\hline Docetaxel dose & 1.01 & $0.99-1.03$ & 0.266 & 1.08 & $1.03-1.13$ & 0.001 \\
\hline $\mathrm{PS}>1$ & 0.99 & $0.96-1.01$ & 0.287 & 0.99 & $0.96-1.02$ & 0.444 \\
\hline Median age & 0.97 & $0.91-1.03$ & 0.300 & 1.02 & $0.94-1.10$ & 0.598 \\
\hline Percentage of female & 1.01 & $1.00-1.02$ & 0.082 & \multicolumn{3}{|c|}{ Excluded } \\
\hline Treatment line ( $\geq 2$ nd line) & 0.50 & $0.24-1.02$ & 0.057 & \multicolumn{3}{|c|}{ Excluded } \\
\hline
\end{tabular}

$O R$ odds ratio, $C I$ confidence interval, $P S>1$ percentage of the participants whose performance status was $>1$ 
cancer patients who received the same cytotoxic chemotherapy regimen, paclitaxel plus carboplatin [128]. The researchers discussed the possible causes of these differences and suggested that the allelic distribution of the genes involved in paclitaxel disposition or DNA repair was a significant factor. Such an approach may be very useful in determining the mechanisms that cause ethnic differences in drug effects and toxicity. Docetaxel pharmacokinetics is dominated by the hepatic cytochrome P450 3A (CYP3A) subfamily and P-glycoprotein, which are partly involved in paclitaxel disposition [129]. These facts indicate that similar pharmacogenomic differences might have some role in the ethnic differences in docetaxel toxicity. Population pharmacokinetic studies of docetaxel were performed in Western countries and Japan to harmonize drug development in the two regions. In these studies, researchers concluded that the systemic clearance of docetaxel was almost similar between Western and Japanese participants with the same variables, including hepatic function, serum albumin level, serum $\alpha_{1-}$ acid glycoprotein (AAG) level, and age [130, 131].

Individualized dosing of docetaxel is one of the potential solutions for pharmacoethnicity. On the other hand, there are many barriers and unknown variables in achieving satisfactory individualization. Yamamoto et al. [132] reported that docetaxel dosing based on CYP3A function using the hydration ratio of externally administered cortisol as a probe improved pharmacokinetic variability, but not pharmacodynamic variability. These results indicate a possible divergence in systemic pharmacokinetics and local exposure of the drug. Systemic exposure of cytotoxic agents is not the only factor but is one of the major factors that influence myelotoxicity, because drug transport into hematopoietic progenitor cells may be a critical point in the differential expression of toxicity [133, 134].

Our study has some limitations in terms of design. The classification criterion used in our analysis might not accurately reflect the ethnicity of the participants because we classified studies by the region in which they were mainly conducted, not by the race of the participants. We decided to use this criterion because most of the published studies did not report the demographic background of the participants with respect to race. We believe that the results of our study might reflect not only racial differences but also other regional factors such as environment and social divergence. This study was based on the published data, which were aggregated as means or medians; however, this approach loses considerable information about each participant. For example, the effects of some variables including the patients' age and performance status, which are known to be variables that affect chemotherapyinduced neutropenia, were not significant in our study. In addition, we could not obtain some variables for the majority of the study subjects. For example, the interval of complete blood count (CBC interval) monitoring affects the incidence of severe neutropenia. Only 84 of the 128 arms $(65 \%)$ contained information about the $\mathrm{CBC}$ interval. In the sub-analysis using these $84 \mathrm{arms}$, the $\mathrm{CBC}$ interval showed a significant negative relationship with outcome in the univariate analysis. Bruno et al. [135] reported that the AAG level, docetaxel clearance, baseline count of neutrophils, and number of previous regimens were significant predictors of grade 4 neutropenia. In our analysis, we could not obtain data on the AAG level from each paper because it was not routinely measured in the clinical setting or clinical trials. The baseline neutrophil count and hepatic enzyme level were not taken into consideration in our analysis because most of the studies have eligibility criteria according to blood cell counts and blood chemicals.

In conclusion, there is a significant difference in the incidence of docetaxel-induced severe neutropenia between Asian and non-Asian studies. Physicians and pharmacists should therefore consider ethnic diversity in docetaxel toxicity when interpreting the results of clinical trials.

Conflict of interest The authors declare no conflict of interest.

\section{References}

1. O'Donnell PH, Dolan ME (2009) Cancer pharmacoethnicity: ethnic differences in susceptibility to the effects of chemotherapy. Clin Cancer Res 15:4806-4814

2. Huang SM, Temple R (2008) Is this the drug or dose for you? Impact and consideration of ethnic factors in global drug development, regulatory review, and clinical practice. Clin Pharmacol Ther 84:287-294

3. Thatcher N, Chang A, Parikh P et al (2005) Gefitinib plus best supportive care in previously treated patients with refractory advanced non-small-cell lung cancer: results from a randomized, placebo-controlled, multicentre study (Iressa Survival Evaluation in Lung Cancer). Lancet 366:1527-1537

4. Hirsch FR, Varella-Garcia M, Bunn PA Jr et al (2006) Molecular predictors of outcome with gefitinib in a phase III placebocontrolled study in advanced non-small-cell lung cancer. J Clin Oncol 24:5034-5042

5. Noda K, Nishiwaki Y, Kawahara M et al (2002) Irinotecan plus cisplatin compared with etoposide plus cisplatin for extensive small-cell lung cancer. N Engl J Med 346:85-91

6. Hanna N, Bunn PA Jr, Langer C et al (2006) Randomized phase III trial comparing irinotecan/cisplatin with etoposide/cisplatin in patients with previously untreated extensive stage disease small-cell lung cancer. J Clin Oncol 24:2038-2043

7. Lara PN Jr, Natale R, Crowley J et al (2009) Phase III trial of irinotecan/cisplatin compared with etoposide/cisplatin in extensive-stage small-cell lung cancer: clinical and pharmacogenomic results from SWOG S0124. J Clin Oncol 27: 2530-2535

8. Naito S, Tsukamoto T, Koga H et al (2008) Docetaxel plus prednisolone for the treatment of metastatic hormone-refractory prostate cancer: a multicenter phase II trial in Japan. Jpn J Clin Oncol 38:365-372 
9. Tannock IF, de Wit R, Berry WR et al (2004) Docetaxel plus prednisone or mitoxantrone plus prednisone for advanced prostate cancer. N Engl J Med 351:1502-1512

10. Campora E, Colloca G, Ratti R et al (2008) Docetaxel for metastatic breast cancer: two consecutive phase II trials. Anticancer Res 28:3993-3995

11. Kim ES, Hirsh V, Mok T et al (2008) Gefitinib versus docetaxel in previously treated non-small-cell lung cancer (INTEREST): a randomised phase III trial. Lancet 372:1809-1818

12. Maruyama R, Nishiwaki Y, Tamura T et al (2008) Phase III study, V-15-32, of gefitinib versus docetaxel in previously treated Japanese patients with non-small-cell lung cancer. J Clin Oncol 26:4244-4252

13. Kunitoh H, Kato H, Tsuboi M et al (2008) A randomised phase II trial of preoperative chemotherapy of cisplatin-docetaxel or docetaxel alone for clinical stage IB/II non-small-cell lung cancer results of a Japan Clinical Oncology Group trial (JCOG 0204). Br J Cancer 99:852-857

14. Jones S, Thompson D, Barton J et al (2008) A randomized phase II trial of oral topotecan versus docetaxel in the second-line treatment of non-small-cell lung cancer. Clin Lung Cancer 9:154-159

15. Caffo O, Sava T, Comploj E et al (2008) Docetaxel, with or without estramustine phosphate, as first-line chemotherapy for hormone-refractory prostate cancer: results of a multicentre, randomized phase II trial. BJU Int 102:1080-1085

16. Paz-Ares L, Ross H, O'Brien M et al (2008) Phase III trial comparing paclitaxel poliglumex vs docetaxel in the second-line treatment of non-small-cell lung cancer. $\mathrm{Br} \mathrm{J}$ Cancer 98: $1608-1613$

17. Rivera E, Mejia JA, Arun BK et al (2008) Phase 3 study comparing the use of docetaxel on an every-3-week versus weekly schedule in the treatment of metastatic breast cancer. Cancer 112:1455-1461

18. Albertsson M, Johansson B, Friesland S et al (2007) Phase II studies on docetaxel alone every third week, or weekly in combination with gemcitabine in patients with primary locally advanced, metastatic, or recurrent esophageal cancer. Med Oncol 24:407-412

19. Heymach JV, Johnson BE, Prager D et al (2007) Randomized, placebo-controlled phase II study of vandetanib plus docetaxel in previously treated non small-cell lung cancer. J Clin Oncol 25:4270-4277

20. Georgoulias V, Androulakis N, Kotsakis A et al (2008) Docetaxel versus docetaxel plus gemcitabine as front-line treatment of patients with advanced non-small cell lung cancer: a randomized, multicenter phase III trial. Lung Cancer 59:57-63

21. Garcia AA, Blessing JA, Vaccarello L et al (2007) Phase II clinical trial of docetaxel in refractory squamous cell carcinoma of the cervix: a Gynecologic Oncology Group Study. Am J Clin Oncol 30:428-431

22. Maruta F, Ishizone S, Hiraguri M et al (2007) A clinical study of docetaxel with or without $5^{\prime}$ DFUR as a second-line chemotherapy for advanced gastric cancer. Med Oncol 24:71-75

23. Baur M, van Oosterom AT, Diéras V et al (2008) A phase II trial of docetaxel (Taxotere) as second-line chemotherapy in patients with metastatic breast cancer. J Cancer Res Clin Oncol 134:125-135

24. Lee JL, Ryu MH, Chang HM et al (2008) A phase II study of docetaxel as salvage chemotherapy in advanced gastric cancer after failure of fluoropyrimidine and platinum combination chemotherapy. Cancer Chemother Pharmacol 61:631-637

25. Eymard JC, Priou F, Zannetti A et al (2007) Randomized phase II study of docetaxel plus estramustine and single-agent docetaxel in patients with metastatic hormone-refractory prostate cancer. Ann Oncol 18:1064-1070
26. Lilenbaum R, Rubin M, Samuel J et al (2007) A randomized phase II trial of two schedules of docetaxel in elderly or poor performance status patients with advanced non-small cell lung cancer. J Thorac Oncol 2:306-311

27. Harvey V, Mouridsen H, Semiglazov V et al (2006) Phase III trial comparing three doses of docetaxel for second-line treatment of advanced breast cancer. J Clin Oncol 24:4963-4970

28. Laber DA, Glisson SD, Hargis JB et al (2006) A phase II study of higher dose docetaxel in androgen-independent prostate cancer. Am J Clin Oncol 29:389-394

29. Kudoh S, Takeda K, Nakagawa K et al (2006) Phase III study of docetaxel compared with vinorelbine in elderly patients with advanced non-small-cell lung cancer: results of the West Japan Thoracic Oncology Group Trial (WJTOG 9904). J Clin Oncol 24:3657-3663

30. Ramlau R, Gervais R, Krzakowski M et al (2006) Phase III study comparing oral topotecan to intravenous docetaxel in patients with pretreated advanced non-small-cell lung cancer. J Clin Oncol 24:2800-2807

31. Hebbar M, Ernst O, Cattan S et al (2006) Phase II trial of docetaxel therapy in patients with advanced hepatocellular carcinoma. Oncology 70:154-158

32. Pacilio C, Morabito A, Nuzzo F et al (2006) Is epirubicin effective in first-line chemotherapy of metastatic breast cancer (MBC) after an epirubicin-containing adjuvant treatment? A single centre phase III trial. Br J Cancer 94:1233-1236

33. Chen YM, Shih JF, Perng RP et al (2006) A randomized trial of different docetaxel schedules in non-small cell lung cancer patients who failed previous platinum-based chemotherapy. Chest 129:1031-1038

34. Camps C, Massuti B, Jiménez A et al (2006) Randomized phase III study of 3-weekly versus weekly docetaxel in pretreated advanced non-small-cell lung cancer: a Spanish Lung Cancer Group trial. Ann Oncol 17:467-472

35. Cufer T, Vrdoljak E, Gaafar R et al (2006) Phase II, open-label, randomized study (SIGN) of single-agent gefitinib (IRESSA) or docetaxel as second-line therapy in patients with advanced (stage IIIb or IV) non-small-cell lung cancer. Anticancer Drugs 17:401-409

36. Lai CL, Tsai CM, Chiu CH et al (2005) Phase II randomized trial of tri-weekly versus days 1 and 8 weekly docetaxel as a second-line treatment of advanced non-small cell lung cancer. Jpn J Clin Oncol 35:700-706

37. Schuette W, Nagel S, Blankenburg T et al (2005) Phase III study of second-line chemotherapy for advanced non-small-cell lung cancer with weekly compared with 3-weekly docetaxel. J Clin Oncol 23:8389-8395

38. Katsumata N, Noda K, Nozawa S et al (2005) Phase II trial of docetaxel in advanced or metastatic endometrial cancer: a Japanese Cooperative Study. Br J Cancer 93:999-1004

39. Jones SE, Erban J, Overmoyer B et al (2005) Randomized phase III study of docetaxel compared with paclitaxel in metastatic breast cancer. J Clin Oncol 23:5542-5551

40. Pectasides D, Pectasides M, Farmakis D et al (2005) Comparison of docetaxel and docetaxel-irinotecan combination as second-line chemotherapy in advanced non-small-cell lung cancer: a randomized phase II trial. Ann Oncol 16:294-299

41. Ishikawa T, Shimizu S, Inaba M et al (2004) A multicenter phase II study of docetaxel $60 \mathrm{mg} / \mathrm{m}^{2}$ as first-line chemotherapy in patients with advanced or recurrent breast cancer. Breast Cancer 11:374-379

42. Gervais R, Ducolone A, Breton JL et al (2005) Phase II randomised trial comparing docetaxel given every 3 weeks with weekly schedule as second-line therapy in patients with advanced non-small-cell lung cancer (NSCLC). Ann Oncol 16:90-96 
43. Wachters FM, Groen HJ, Biesma B et al (2005) A randomised phase II trial of docetaxel vs docetaxel and irinotecan in patients with stage IIIb-IV non-small-cell lung cancer who failed firstline treatment. Br J Cancer 92:15-20

44. Gridelli C, Gallo C, Di Maio M et al (2004) A randomised clinical trial of two docetaxel regimens (weekly vs 3 week) in the second-line treatment of non-small-cell lung cancer. The DISTAL 01 study. Br J Cancer 91:1996-2004

45. Kulke MH, Kim H, Stuart K et al (2004) A phase II study of docetaxel in patients with metastatic carcinoid tumors. Cancer Invest 22:353-359

46. Tabernero J, Climent MA, Lluch A et al (2004) A multicentre, randomised phase II study of weekly or 3-weekly docetaxel in patients with metastatic breast cancer. Ann Oncol 15:1358-1365

47. Georgoulias V, Ardavanis A, Agelidou A et al (2004) Docetaxel versus docetaxel plus cisplatin as front-line treatment of patients with advanced non-small-cell lung cancer: a randomized, multicenter phase III trial. J Clin Oncol 22:2602-2609

48. Muro K, Hamaguchi T, Ohtsu A et al (2004) A phase II study of single-agent docetaxel in patients with metastatic esophageal cancer. Ann Oncol 15:955-959

49. Takigawa N, Segawa Y, Kishino D et al (2004) Clinical and pharmacokinetic study of docetaxel in elderly non-small-cell lung cancer patients. Cancer Chemother Pharmacol 54:230-236

50. Hanna N, Shepherd FA, Fossella FV et al (2004) Randomized phase III trial of pemetrexed versus docetaxel in patients with non-small-cell lung cancer previously treated with chemotherapy. J Clin Oncol 22:1589-1597

51. Quoix E, Lebeau B, Depierre A et al (2004) Randomised, multicentre phase II study assessing two doses of docetaxel (75 or $100 \mathrm{mg} / \mathrm{m}^{2}$ ) as second-line monotherapy for non-small-cell lung cancer. Ann Oncol 15:38-44

52. Giuliani F, Gebbia V, De Vita F et al (2003) Docetaxel as salvage therapy in advanced gastric cancer: a phase II study of the Gruppo Oncologico Italia Meridionale (G.O.I.M.). Anticancer Res 23:4219-4222

53. Vallejo CT, Machiavelli MR, Pérez JE et al (2003) Docetaxel as neoadjuvant chemotherapy in patients with advanced cervical carcinoma. Am J Clin Oncol 26:477-482

54. Rose PG, Blessing JA, Ball HG et al (2003) A phase II study of docetaxel in paclitaxel-resistant ovarian and peritoneal carcinoma: a Gynecologic Oncology Group study. Gynecol Oncol $88: 130-135$

55. Mattson KV, Abratt RP, ten Velde G et al (2003) Docetaxel as neoadjuvant therapy for radically treatable stage III non-smallcell lung cancer: a multinational randomised phase III study. Ann Oncol 14:116-122

56. Bonneterre J, Roché H, Monnier A et al (2002) Docetaxel vs 5 -fluorouracil plus vinorelbine in metastatic breast cancer after anthracycline therapy failure. Br J Cancer 87:1210-1215

57. Bang YJ, Kang WK, Kang YK et al (2002) Docetaxel 75 mg/ $\mathrm{m}(2)$ is active and well tolerated in patients with metastatic or recurrent gastric cancer: a phase II trial. Jpn J Clin Oncol $32: 248-254$

58. Lenzi R, Yalcin S, Evans DB et al (2002) Phase II study of docetaxel in patients with pancreatic cancer previously untreated with cytotoxic chemotherapy. Cancer Invest 20:464-472

59. Heath EI, Urba S, Marshall J et al (2002) Phase II trial of docetaxel chemotherapy in patients with incurable adenocarcinoma of the esophagus. Invest New Drugs 20:95-99

60. Vorobiof DA, Rapoport BL, Chasen MR et al (2002) Malignant pleural mesothelioma: a phase II trial with docetaxel. Ann Oncol $13: 412-415$

61. Köstler WJ, Brodowicz T, Attems Y et al (2001) Docetaxel as rescue medication in anthracycline- and ifosfamide-resistant locally advanced or metastatic soft tissue sarcoma: results of a phase II trial. Ann Oncol 12:1281-1288

62. Papakostas P, Kouroussis C, Androulakis N et al (2001) Firstline chemotherapy with docetaxel for unresectable or metastatic carcinoma of the biliary tract. A multicentre phase II study. Eur J Cancer 37:1833-1838

63. Katsumata N, Tsunematsu R, Tanaka K et al (2000) A phase II trial of docetaxel in platinum pre-treated patients with advanced epithelial ovarian cancer: a Japanese cooperative study. Ann Oncol 11:1531-1536

64. Perng RP, Shih JF, Chen YM et al (2000) A phase II study of single-agent docetaxel chemotherapy for non-small cell lung cancer. Jpn J Clin Oncol 30:429-434

65. Vici P, Belli F, Di Lauro L et al (2000) Docetaxel in patients with anthracycline-resistant advanced breast cancer. Oncology 60:60-65

66. Mattson K, Bosquee L, Dabouis G et al (2000) Phase II study of docetaxel in the treatment of patients with advanced non-small cell lung cancer in routine daily practice. Lung Cancer 29:205-216

67. Coleman RE, Howell A, Eggleton SP et al (2000) Phase II study of docetaxel in patients with liver metastases from breast cancer. UK study group. Ann Oncol 11:541-546

68. Rougier P, Adenis A, Ducreux M et al (2000) A phase II study: docetaxel as first-line chemotherapy for advanced pancreatic adenocarcinoma. Eur J Cancer 36:1016-1025

69. Goh BC, Lehnert M, Lim HL et al (2000) Phase II trial of docetaxel in Asian patients with inoperable stage III non-small cell lung cancer. Acta Oncol 39:225-229

70. Shepherd FA, Dancey J, Ramlau R et al (2000) Prospective randomized trial of docetaxel versus best supportive care in patients with non-small-cell lung cancer previously treated with platinum-based chemotherapy. J Clin Oncol 18:2095-2103

71. Verweij J, Lee SM, Ruka W et al (2000) Randomized phase II study of docetaxel versus doxorubicin in first- and second-line chemotherapy for locally advanced or metastatic soft tissue sarcomas in adults: a study of the European Organization for Research and Treatment of Cancer Soft Tissue and Bone Sarcoma Group. J Clin Oncol 18:2081-2086

72. Roszkowski K, Pluzanska A, Krzakowski M et al (2000) A multicenter, randomized, phase III study of docetaxel plus best supportive care versus best supportive care in chemotherapynaive patients with metastatic or non-resectable localized nonsmall cell lung cancer (NSCLC). Lung Cancer 27:145-157

73. Gandara DR, Vokes E, Green M et al (2000) Activity of docetaxel in platinum-treated non-small-cell lung cancer: results of a phase II multicenter trial. J Clin Oncol 18:131-135

74. Friedland D, Cohen J, Miller R Jr et al (1999) A phase II trial of docetaxel (Taxotere) in hormone-refractory prostate cancer: correlation of antitumor effect to phosphorylation of $\mathrm{Bcl}-2$. Semin Oncol 26:19-23

75. Chan S, Friedrichs K, Noel D et al (1999) Prospective randomized trial of docetaxel versus doxorubicin in patients with metastatic breast cancer. J Clin Oncol 17:2341-2354

76. Alexopoulos CG, Rigatos G, Efremidis AP et al (1999) A phase II study of the effectiveness of docetaxel (Taxotere) in women with advanced breast cancer previously treated with polychemotherapy. Hellenic Cooperative Interhospital Group in Oncology. Cancer Chemother Pharmacol 44:253-258

77. Hesketh PJ, Crowley JJ, Burris HA 3rd et al (1999) Evaluation of docetaxel in previously untreated extensive-stage small cell lung cancer: a Southwest Oncology Group phase II trial. Cancer J Sci Am 5:237-241

78. Okada S, Sakata Y, Matsuno S et al (1999) Phase II study of docetaxel in patients with metastatic pancreatic cancer: a 
Japanese cooperative study. Cooperative Group of Docetaxel for Pancreatic Cancer in Japan. Br J Cancer 80:438-443

79. Latreille J, Gelmon KA, Hirsh V et al (1999) Phase II trial of docetaxel with dexamethasone premedication in patients with advanced non-small cell lung cancer: the Canadian experience. Invest New Drugs 16:265-270

80. Nabholtz JM, Senn HJ, Bezwoda WR et al (1999) Prospective randomized trial of docetaxel versus mitomycin plus vinblastine in patients with metastatic breast cancer progressing despite previous anthracycline-containing chemotherapy. 304 Study Group. J Clin Oncol 17:1413-1424

81. Mai M, Sakata Y, Kanamaru R et al (1999) A late phase II clinical study of RP56976 (docetaxel) in patients with advanced or recurrent gastric cancer: a cooperative study group trial (group B). Gan To Kagaku Ryoho 26:487-496 (in Japanese)

82. Pazdur R, Royce ME, Rodriguez GI et al (1999) Phase II trial of docetaxel for cholangiocarcinoma. Am J Clin Oncol 22:78-81

83. Inuyama Y, Kataura A, Togawa K et al (1999) Late phase II clinical study of RP56976 (docetaxel) in patients with advanced/ recurrent head and neck cancer. Gan To Kagaku Ryoho 26: 107-116 (in Japanese)

84. de Wit R, Kruit WH, Stoter G et al (1998) Docetaxel (Taxotere): an active agent in metastatic urothelial cancer; results of a phase II study in non-chemotherapy-pretreated patients. Br J Cancer 78:1342-1345

85. Taguchi T, Sakata Y, Kanamaru R et al (1998) Late phase II clinical study of RP56976 (docetaxel) in patients with advanced/ recurrent gastric cancer: a Japanese Cooperative Study Group trial (group A). Gan To Kagaku Ryoho 25:1915-1924 (in Japanese)

86. Valero V, Jones SE, Von Hoff DD et al (1998) A phase II study of docetaxel in patients with paclitaxel-resistant metastatic breast cancer. J Clin Oncol 16:3362-3368

87. Clark TB, Kemeny NE, Conti JA et al (1998) Phase II trial of docetaxel (Taxotere) for untreated advanced colorectal carcinoma. Cancer Invest 16:314-318

88. Budman DR, Petroni GR, Johnson JL et al (1997) Phase II trial of docetaxel in non-Hodgkin's lymphomas: a study of the Cancer and Leukemia Group B. J Clin Oncol 15:3275-3279

89. McCaffrey JA, Hilton S, Mazumdar M et al (1997) Phase II trial of docetaxel in patients with advanced or metastatic transitionalcell carcinoma. J Clin Oncol 15:1853-1857

90. Dieras V, Chevallier B, Kerbrat P et al (1996) A multicentre phase II study of docetaxel $75 \mathrm{mg} \mathrm{m}^{-2}$ as first-line chemotherapy for patients with advanced breast cancer: report of the Clinical Screening Group of the EORTC. European Organization for Research and Treatment of Cancer. $\mathrm{Br} \mathrm{J}$ Cancer 74:650-656

91. Einzig AI, Schuchter LM, Recio A et al (1996) Phase II trial of docetaxel (Taxotere) in patients with metastatic melanoma previously untreated with cytotoxic chemotherapy. Med Oncol 13:111-117

92. Einzig AI, Neuberg D, Remick SC et al (1996) Phase II trial of docetaxel (Taxotere) in patients with adenocarcinoma of the upper gastrointestinal tract previously untreated with cytotoxic chemotherapy: the Eastern Cooperative Oncology Group (ECOG) results of protocol E1293. Med Oncol 13:87-93

93. Kudelka AP, Verschraegen CF, Levy T et al (1996) Preliminary report of the activity of docetaxel in advanced or recurrent squamous cell cancer of the cervix. Anticancer Drugs 7:398-401

94. Kavanagh JJ, Kudelka AP, de Leon CG et al (1996) Phase II study of docetaxel in patients with epithelial ovarian carcinoma refractory to platinum. Clin Cancer Res 2:837-842

95. Kunitoh H, Watanabe K, Onoshi T et al (1996) Phase II trial of docetaxel in previously untreated advanced non-small-cell lung cancer: a Japanese cooperative study. J Clin Oncol 14: $1649-1655$
96. Fumoleau P, Chevallier B, Kerbrat P et al (1996) A multicentre phase II study of the efficacy and safety of docetaxel as first-line treatment of advanced breast cancer: report of the Clinical Screening Group of the EORTC. Ann Oncol 7:165-171

97. Hudis CA, Seidman AD, Crown JP et al (1996) Phase II and pharmacologic study of docetaxel as initial chemotherapy for metastatic breast cancer. J Clin Oncol 14:58-65

98. Adachi I, Watanabe T, Takashima S et al (1996) A late phase II study of RP56976 (docetaxel) in patients with advanced or recurrent breast cancer. Br J Cancer 73:210-216

99. Bedikian AY, Weiss GR, Legha SS et al (1995) Phase II trial of docetaxel in patients with advanced cutaneous malignant melanoma previously untreated with chemotherapy. J Clin Oncol 13:2895-2899

100. Valero V, Holmes FA, Walters RS et al (1995) Phase II trial of docetaxel: a new, highly effective antineoplastic agent in the management of patients with anthracycline-resistant metastatic breast cancer. J Clin Oncol 13:2886-2894

101. Ravdin PM, Burris HA 3rd, Cook G et al (1995) Phase II trial of docetaxel in advanced anthracycline-resistant or anthracenedione-resistant breast cancer. J Clin Oncol 13:2879-2885

102. Fossella FV, Lee JS, Shin DM et al (1995) Phase II study of docetaxel for advanced or metastatic platinum-refractory nonsmall-cell lung cancer. J Clin Oncol 13:645-651

103. Miller VA, Rigas JR, Francis PA et al (1995) Phase II trial of a $75-\mathrm{mg} / \mathrm{m}^{2}$ dose of docetaxel with prednisone premedication for patients with advanced non-small cell lung cancer. Cancer 75:968-972

104. Chevallier B, Fumoleau P, Kerbrat P et al (1995) Docetaxel is a major cytotoxic drug for the treatment of advanced breast cancer: a phase II trial of the Clinical Screening Cooperative Group of the European Organization for Research and Treatment of Cancer. J Clin Oncol 13:314-322

105. Onoshi T, Watanabe K, Furuse K et al (1995) Late phase II trial of RP56976 (Docetaxel) in patients with non-small-cell lung cancer. Gan To Kagaku Ryoho 22:59-65 (in Japanese)

106. Taguchi T, Mori S, Abe R et al (1994) Late phase II clinical study of RP56976 (docetaxel) in patients with advanced/recurrent breast cancer. Gan To Kagaku Ryoho 21:2625-2632 (in Japanese)

107. Kudo S, Hino M, Fujita A et al (1994) Late phase II clinical study of RP56976 (docetaxel) in patients with non-small cell lung cancer. Gan To Kagaku Ryoho 21:2617-2623 (in Japanese)

108. Yokoyama A, Kurita Y, Watanabe K et al (1994) Early phase II clinical study of RP56976 (docetaxel) in patients with primary pulmonary cancer. Docetaxel Cooperative Study Group for Lung Cancer. Gan To Kagaku Ryoho 21:2609-2616 (in Japanese)

109. Francis P, Schneider J, Hann L et al (1994) Phase II trial of docetaxel in patients with platinum-refractory advanced ovarian cancer. J Clin Oncol 12:2301-2308

110. Noda K, Terajima Y, Ogita Y et al (1994) Phase II clinical study of RP56976 (docetaxel) in patients with carcinoma ovarii or carcinoma colli uteri. Gan To Kagaku Ryoho 21:2471-2477 (in Japanese)

111. Taguchi T, Hirata K, Kunii Y et al (1994) An early phase II clinical study of RP56976 (docetaxel) in patients with breast cancer. Gan To Kagaku Ryoho 21:2453-2460 (in Japanese)

112. Taguchi T (1994) An early phase II clinical study of RP56976 (docetaxel) in patients with cancer of the gastrointestinal tract. Gan To Kagaku Ryoho 21:2431-2437 (in Japanese)

113. Sulkes A, Smyth J, Sessa C et al (1994) Docetaxel (Taxotere) in advanced gastric cancer: results of a phase II clinical trial. EORTC Early Clinical Trials Group. Br J Cancer 70:380-383

114. Sternberg CN, ten Bokkel Huinink WW, Smyth JF et al (1994) Docetaxel (Taxotere), a novel taxoid, in the treatment of 
advanced colorectal carcinoma: an EORTC Early Clinical Trials Group Study. Br J Cancer 70:376-379

115. van Hoesel QG, Verweij J, Catimel G et al (1994) Phase II study with docetaxel (Taxotere) in advanced soft tissue sarcomas of the adult. EORTC Soft Tissue and Bone Sarcoma Group. Ann Oncol 5:539-542

116. Catimel G, Verweij J, Mattijssen V et al (1994) Docetaxel (Taxotere): an active drug for the treatment of patients with advanced squamous cell carcinoma of the head and neck. EORTC Early Clinical Trials Group. Ann Oncol 5:533-537

117. ten Bokkel Huinink WW, Prove AM, Piccart M et al (1994) A phase II trial with docetaxel (Taxotere) in second line treatment with chemotherapy for advanced breast cancer. A study of the EORTC Early Clinical Trials Group. Ann Oncol 5:527-532

118. Fossella FV, Lee JS, Murphy WK et al (1994) Phase II study of docetaxel for recurrent or metastatic non-small-cell lung cancer. J Clin Oncol 12:1238-1244

119. Francis PA, Rigas JR, Kris MG et al (1994) Phase II trial of docetaxel in patients with stage III and IV non-small-cell lung cancer. J Clin Oncol 12:1232-1237

120. Pazdur R, Lassere Y, Soh LT et al (1994) Phase II trial of docetaxel (Taxotere) in metastatic colorectal carcinoma. Ann Oncol 5:468-470

121. Aamdal S, Wolff I, Kaplan S et al (1994) Docetaxel (Taxotere) in advanced malignant melanoma: a phase II study of the EORTC Early Clinical Trials Group. Eur J Cancer 30:1061-1064

122. Smyth JF, Smith IE, Sessa C et al (1994) Activity of docetaxel (Taxotere) in small cell lung cancer. The Early Clinical Trials Group of the EORTC. Eur J Cancer 30:1058-1060

123. Sparano JA, Makhson AN, Semiglazov VF et al (2009) Pegylated liposomal doxorubicin plus docetaxel significantly improves time to progression without additive cardiotoxicity compared with docetaxel monotherapy in patients with advanced breast cancer previously treated with neoadjuvantadjuvant anthracycline therapy: results from a randomized phase III study. J Clin Oncol 27:4522-4529

124. Gradishar WJ, Krasnojon D, Cheporov S et al (2009) Significantly longer progression-free survival with nab-paclitaxel compared with docetaxel as first-line therapy for metastatic breast cancer. J Clin Oncol 27:3611-3619

125. Katsumata N, Watanabe T, Minami H et al (2009) Phase III trial of doxorubicin plus cyclophosphamide (AC), docetaxel, and alternating AC and docetaxel as front-line chemotherapy for metastatic breast cancer: Japan Clinical Oncology Group trial (JCOG9802). Ann Oncol 20:1210-1215
126. Ruff P, Vorobiof DA, Jordaan JP et al (2009) A randomized, placebo-controlled, double-blind phase 2 study of docetaxel compared to docetaxel plus zosuquidar (LY335979) in women with metastatic or locally recurrent breast cancer who have received one prior chemotherapy regimen. Cancer Chemother Pharmacol 64:763-768

127. Takeda K, Negoro S, Tamura T et al (2009) Phase III trial of docetaxel plus gemcitabine versus docetaxel in second-line treatment for non-small-cell lung cancer: results of a Japan Clinical Oncology Group trial (JCOG0104). Ann Oncol 20:835-841

128. Gandara DR, Kawaguchi T, Crowley J et al (2009) Japanese-US common-arm analysis of paclitaxel plus carboplatin in advanced non-small-cell lung cancer: a model for assessing populationrelated pharmacogenomics. J Clin Oncol 27:3540-3546

129. Marre F, Sanderink GJ, de Sousa G et al (1996) Hepatic biotransformation of docetaxel (Taxotere) in vitro: involvement of the CYP3A subfamily in humans. Cancer Res 56:1296-1302

130. Tanigawara Y, Sasaki Y, Otsu T et al (1996) Population pharmacokinetics of docetaxel in Japanese patients. Proc Am Soc Clin Oncol 15 (abstract)

131. Tanigawara Y (1997) Recent applications of the population pharmacokinetic approach: pre-marketing and post-marketing. In: Aarons L, Balant LP, Danhof M et al (eds) The population approach: measuring and managing variability in response, concentration and dose. European Commission, Brussels, pp 25-37

132. Yamamoto N, Tamura T, Murakami H et al (2005) Randomized pharmacokinetic and pharmacodynamic study of docetaxel: dosing based on body-surface area compared with individualized dosing based on cytochrome P450 activity estimated using a urinary metabolite of exogenous cortisol. J Clin Oncol 23:1061-1069

133. Chaudhary PM, Roninson IB (1991) Expression and activity of P-glycoprotein, a multidrug efflux pump, in human hematopoietic stem cells. Cell 66:85-94

134. Guo CB, Li YC, Jin XQ (2006) Chemoprotection effect of retroviral vector encoding multidrug resistance 1 gene to allow intensified chemotherapy in vivo. Cancer Chemother Pharmacol 58:40-49

135. Bruno R, Hille D, Riva A et al (1998) Population pharmacokinetics/pharmacodynamics of docetaxel in phase II studies in patients with cancer. J Clin Oncol 16:187-196 